\title{
Introducing the Team Based Learning as an Approach to Reviving Interest in Biochemistry amongst Undergraduate Medical Students-An Exploratory Study
}

\author{
Vanita Lal ${ }^{1}$, Bharti Bhandari ${ }^{2}$, Garima Gupta ${ }^{l}$, Kuldeep Singh $^{3}$, Praveen Sharma ${ }^{l}$ \\ Dept. of Biochemistry ${ }^{1}$, Dept. of Physiology ${ }^{2}$, Dept. of Paeditrics ${ }^{3}$, \\ All India Institute of Medical Sciences, Jodhpur.
}

\begin{abstract}
Introduction: Much emphasis has been given to different approaches to active learning. Our primary objective was to elicit interest amongst students in the areas of neglected, difficult topics in Biochemistry. Encouraging team building and developing team spirit by roping in all students in the exercise was the secondary objective of our study.
\end{abstract}

Methods: It was a single blind controlled interventional study. A Team Based Learning (TBL) Module was developed for First Professional MBBS students of 2015 batch. The topics selected were of high difficulty level. Ten groups were formed by random allocation. Study materials and reference sources were displayed and distributed two weeks prior to the initiation of TBL sessions. Each TBL session consisted of pre-test preparation (through didactic lectures and self-study), MCQ-based pre-test, application of concepts, Problem Based Questions (PBQs), reviewing and post-test. This was followed by administration of feedback questionnaire. The data obtained were analysed using SPSS version 21.

Results: When the pre-test and post-test marks were compared, significant improvement in the students' performance was observed $(\mathrm{p}<0.05)$. According to students' feedback, the learning exercise was innovative, beneficial, helped in better comprehension of difficult topics, increased in-depth knowledge on the topic, fun-filled and relaxing, eventually leading to better learning. Students were able to analyse and give rational and logical responses to complex PBQs. There was an increase in interest towards reading and referring in detail about the topics allotted to them. Library usage and issue of reference books as seen in the logbook increased rapidly. They were more confident in Biochemistry after conducting a series of TBL sessions. While comparing the performance marks after the TBL sessions with that after classroom didactic lecture method, students were of the view that TBL was better than lectures. The difference in scores obtained by two groups (2016 vs. 2015) was significant. The groups who were exposed to TBL had far better scores than those exposed to lectures in the same topic.

Conclusion: The focus these days is on self-directed learning for medical students to become selfregulated, independent learners, which is essential for acquiring competencies and TBL appears to be one such modality.

Keywords: Active learning, team-based learning, problem-based questions, student-centric learning, feedback questionnaire, self-directed learning.

Correspondence: Dr. Vanita Lal, Department of Biochemistry, AIIMS, Basni, Phase-II, Jodhpur342005, Rajasthan. Mob:+91-8003996875. 


\section{Introduction}

Biochemistry as a subject in the MBBS course is difficult and seems quite intangible to the new medical students. In addition, lack of motivation to learn the subject further adds to the already existing poor attitude towards the subject. To overcome these pitfalls and to generate interest in this basic medical subject, one must come up with innovative ideas of teaching and learning, hence knowledge acquisition through interaction by team-based learning (TBL) or small group discussions is advocated. Of late, much emphasis is being given in active learning approaches for difficult subjects $(1,2)$. Active learning is a teachinglearning process in which students are actively engaged in various learning activities, such as reading, conceptualizing, discussion, or problem solving that promote analysis, synthesis, and evaluation of lecture contents (1-3). Team learning is an approach to large-group teaching that combines the assets of small-group interactive learning with facilitator-motivated content delivery (4). Team learning is being used effectively in professional disciplines other than medicine. We hypothesise that TBL has the potential to enhance the knowledge and improve the attitude and skills of large number of students and not a handful as does a small group discussion. This would ultimately result in better ways to learn the difficult aspects of Medicine. More so, it is not a well-tested method of teaching in Indian context especially in Biochemistry. Some endeavour in Pharmacology (5), Dentistry $(6,7)$ and Microbiology (8) has been initiated lately. Keeping the aforementioned concerns, we planned the TBL module to change the classroom experience from acquiring course content and concepts in a lecture-based format (teacher-centric learning) to applying course content and concepts in a team format (studentcentric learning) and to make difficult topics easier to all.

Rationale of this study: the increasing student/teacher ratio enormously results in a large group that do not comprehend the knowledge imparted. More so the use of power point presentations for large group lectures fades off much of the interest in the topic. So, how much the students support the conventional teaching method as didactic lectures is itself a big question. Hence, TBL was introduced with the aim to prepare students for active, collaborative learning within a similar cohesive group.

\section{Methods}

After obtaining approval from the Scientific Review Committee and the Institute Ethics Committee to carry out the project, the present study was conducted with the First MBBS students in the Department of Biochemistry at our institute. The students were explained about the project in detail and a written informed consent was taken. Ninety nine students participated in the study. The topics selected for TBL were already covered in the form of didactic lectures and were provided two weeks before the pre-test. Study material distribution and the sources for the topics were also provided. The steps of TBL were adapted from the work done by Haidet et al, 2002 and the outline is given in Table 1 (9).

We designed the study by a comprehensive preparation of a Module on the Unit "Biological Catalysis". MCQ based pretest was conducted on Enzymology after delivering didactic lectures on the topics. TBL exercise was planned as a 5 hours' session starting with students completing assigned prereadings or other advanced preparation. Ten teams of 10 students each were formed, except the one team where only nine students were included. According to the group dynamics, each group had a leader, scribe, a reporter and a timekeeper. Orientation and query answering regarding the exercise was undertaken.

Each team made a presentation on the assigned topic followed by discussion on problem-based questions (PBQs.) It was 
Table 1: Steps of Team Based Learning (TBL), adapted from Haidet et al, 2002 and modified according to the situational needs

\begin{tabular}{|c|}
\hline \multicolumn{1}{|c|}{$1^{\text {st }}$ year undergraduate medical students } \\
N=99 \\
\hline Didactic lecture on topics from a specific unit \\
\hline Pre-test on the unit \\
\hline Team formation and their orientation \\
\hline Allocation of subtopics and Problem Based Questions (PBQ) \\
\hline $\begin{array}{c}\text { Formation of faculty review panel ( constituted by the } \\
\text { faculty and senior resident of Biochemistry) }\end{array}$ \\
\hline Presentation and PBQ discussion by the students \\
\hline Post-test on the same topic \\
\hline
\end{tabular}

conducted during the class session and involved the individual, the teams, and the entire class. During the problem-solving process, students were given a worksheet that contained a series of questions to be answered in solving a particular problem. The students worked through the entire worksheet, and then using the simultaneous reporting the facilitator revisited each question and had the student teams to discuss, defend their best choice and analyse their solutions to the questions. The module got to the end with a short instructor-led review and closure activity. It was followed by post-test on the same topic.

Thereafter, post-class reflection was obtained through feedback questionnaire. All 25 items in the Questionnaire set were affirmative. Faculty feedback was also taken using a validated questionnaire.

Validation of the questionnaire set was achieved by the following method. A structured questionnaire was developed and administered to 50 students who were quizzed to gain feedback on the overall suitability of the questionnaire. According to them, the questionnaire was suitable in terms of length and language clarity and did not require any correction. Cronbach's coefficient was 0.65 , suggesting internal reliability of the questionnaire. Mean Content Validity Ratio (CVR) was 0.84 based on the opinions expressed by fellow faculty members.

Statistical analysis was performed using the Graph Pad Prism 5 (Graph Pad Software, Inc., San Diego, California) and SPSS 21 (SPSS Inc., Chicago, Illinois). Kolmogorov-Smirnov test was conducted to assess for normalcy of MCQ scores. The mean and standard deviation of marks obtained was calculated and pre-test and post-test scores were compared using MannWhitney U-test. A $p<0.05$ was taken as statistically significant. We recorded the 
responses of the feedback questionnaire on a Likert scale. The students completed the survey during class time in the presence of the tutors. Anonymity was maintained. Feedback responses of the 99 students in both the groups were recorded and satisfaction index for each item was calculated.

\section{Example of a Module Undertaken}

Allocation: Ten groups were randomly allocated and each was assigned a module. We had reframed a module to exemplify one such module here. One of the group was assigned the subtopic Enzyme Kinetics. The topics were announced two weeks in advance, study materials and other sources provided.

Presentation: It was made by the group leader using chalk and blackboard. No power point presentation was allowed. Time given for the presentation was $12 \pm 3$ minutes each.

PBQs-related to estimation of $\mathrm{V}_{\max }$ and $\mathrm{K}_{\mathrm{m}}$ of prostaglandin endoperoxide synthase by inspection. Prostaglandins are a class of eicosanoids, the fatty acid derivatives with a variety of extremely potent actions on vertebrate tissues. They are responsible for producing fever and inflammation and its associated pain. Prostaglandins are derived from the 20 carbon fatty acid arachidonic acid in a reaction catalysed by the enzyme prostaglandin synthase. This enzyme, a cyclooxygenase, uses oxygen to convert arachidonic acid to $\mathrm{PGG}_{2}$, the immediate precursor of many different prostaglandins. a. The kinetic data given below are for the reaction catalyzed by prostaglandin endoperoxide synthase. Focusing here on the first two columns, determine the $\mathrm{V}_{\text {max }}$ and $\mathrm{K}_{\mathrm{m}}$ of the enzyme.

\begin{tabular}{|c|c|c|}
\hline $\begin{array}{c}\text { Arachidonic } \\
\text { acid }\end{array}$ & $\begin{array}{c}\text { Rate of formation } \\
\text { of } \mathbf{P G G}_{\mathbf{2}}\end{array}$ & $\begin{array}{c}\text { Rate of formation of PGG2 } \\
\text { (with 10mg/ml } \\
\text { ibuprofen/min) }\end{array}$ \\
\hline 0.5 & 23.5 & 16.67 \\
\hline 1.0 & 32.2 & 25.25 \\
\hline 1.5 & 36.9 & 30.49 \\
\hline 2.5 & 41.8 & 37.04 \\
\hline 3.5 & 44.0 & 38.91 \\
\hline
\end{tabular}

b. Ibuprofen is an inhibitor of prostaglandin endoperoxide synthase. By inhibiting the synthesis of prostaglandins, ibuprofen reduces inflammation and pain. Using the data provided, determine the type of inhibition that ibuprofen exerts on prostaglandin endoperoxide synthase (10).

\section{Results}

Mean marks scored by the students in the pre- and post-tests of specified unit are given in Table 2. The marks scored following TBL were significantly higher than the marks scored prior to this exercise $(p<0.05)$.

Mean scores of students in Part Examination in the same Unit (Enzymology) of 2015 Batch (not exposed to TBL sessions) as compared to 2016 Batch (exposed to TBL exercises ) was significantly higher $(\mathrm{p}<0.05)$.

Table 2: Mean marks scored by the students in the pre- and post-tests of specified unit

\begin{tabular}{|c|c|c|}
\hline $\mathrm{N}=99$ & $\begin{array}{c}\text { Mean marks scored } \\
(\mathrm{MM}-15)\end{array}$ & $\begin{array}{c}\text { Mann Whitney U-Test } \\
\mathrm{p} \text { value }\end{array}$ \\
\hline Pre-test & $\begin{array}{c}10.37 \pm 1.99 \\
(\mathrm{CI}: 9.98-10.77)\end{array}$ & $<0.05$ \\
\hline Post-test & $\begin{array}{c}11.70 \pm 2.01 \\
(\mathrm{CI}: 11.30-12.10)\end{array}$ & \\
\hline
\end{tabular}


The feedback from the students on this teaching-learning method activity on a Likert Scale is shown in Table 3.

The average rating was 3.1 , minimum (1.78) for item 11, which specified that the activity helped in overcoming shyness and hesitation in the class. A maximum mean score of 3.57 was obtained for item 7 , which specified that self-study, discussion and team work are the activities that helped in realizing in better understanding of the topic. The Satisfaction Index for each item was calculated using the following formula:

$$
\frac{\left[\left(\mathrm{n}_{1}^{*} 1\right)+\left(\mathrm{n}_{2} * 2\right)+\left(\mathrm{n}_{3} * 3\right)+\left(\mathrm{n}_{4} * 4\right)+\left(\mathrm{n}_{5} * 5\right)\right] * 20}{\left(\mathrm{n}_{1}+\mathrm{n}_{2}+\mathrm{n}_{3}+\mathrm{n}_{4}+\mathrm{n}_{5}\right)}
$$

Where, $\mathrm{n}$ is the total number of students gaining the score mentioned in the subscript for that particular item. It was highest (90.1) for item 3 and lowest (75.4) for item 4 on a 1-100 satisfaction index scale. All 10 items showed Satisfaction Indexes of 75. Most of the students found sessions interesting, according to them, it helped them in better comprehension, in better orientation during didactic lectures on the topic and in improving their analytical ability. Satisfaction Index as calculated from the abovementioned formula is given in Table 3 .

\section{Discussion}

In this study, we carried out a studentcentric active teaching-learning exercise, TBL. We observed that the marks scored in the test following TBL sessions were higher than the marks scored after didactic lectures. Students' feedback revealed that they were satisfied by this teaching approach, and their knowledge, comprehension and interest on the topic increased after the activity. They found the group discussion on difficult aspects very useful and interesting. They appreciated the MCQ-based assessment and viewed coming up for presentation as an opportunity to open and demonstrate their knowledge and communication skills.
TBL exercise is an active learning plan that teaches students to collaborate and work as a team to achieve a common learning objective, thereby increasing individual's strength (11). Prior to conducting TBL, students acquire the required information and concepts by means of conventional didactic lectures, and then they work as team to solve various PBQs. Inspite of working as a team in TBL, each team member is responsible for his own learning outside the class.

Numerous studies have shown the benefits of this mode of active learning as a powerful tool to ingrain in-depth knowledge and increase comprehension of the topic $(12,13)$. Vasan in his study on TBL in Anatomy and Embryology concluded such sessions improve student commitment towards course content. In the study, according to the students' feedback, TBL along with didactic lectures enhanced their understanding of course content and belief that it will help in better performance in their examinations (14). Similar to our findings, Wolff et al, found that TBL sessions lead to increased learning by delivering essential knowledge, contextualizing content, and explaining difficult concepts (15). Mcinerney stated that this way of teaching has a powerful impact on student learning but a significant contribution from facilitators is required for implementing and conducting it properly (16). This mode of teaching-learning is useful not just for the basic sciences but also for acquisition of clinical skills and workshop sessions (17).

Like the responses to feedback, others have also documented that in TBL, students feel actively involved, and it helps them in their learning and in developing team work and communication skills as well (18).

One of the noticeable advantage of TBL is overcoming shyness and developing communication skills by the students not only when one acts as a presenter but also when one is among the audience and articulates the question and participates in the discussion. During the sessions, it was perceived that the students, who 
Table 3: Feedback responses of the 99 students and satisfaction index of each item

\begin{tabular}{|c|c|c|c|c|c|c|c|}
\hline S .No. & Items & $\begin{array}{l}\text { Strongly } \\
\text { Disagree }\end{array}$ & Disagree & Neutral & Agree & $\begin{array}{l}\text { Strongly } \\
\text { Agree }\end{array}$ & $\begin{array}{l}\text { Satisfaction } \\
\text { Index }\end{array}$ \\
\hline 1 & $\begin{array}{l}\text { Team Based Learning was an innovative } \\
\text { way of T/L Method }\end{array}$ & 0 & 2 & 24 & 55 & 5 & 80.3 \\
\hline 2 & $\begin{array}{l}\text { The Team Based Learning Exercise was } \\
\text { useful /beneficial to me }\end{array}$ & 0 & 2 & 8 & 60 & 15 & 82.9 \\
\hline 3 & $\begin{array}{l}\text { I can now rationalize better when asked a } \\
\text { question }\end{array}$ & 0 & 2 & 23 & 55 & 6 & 80.6 \\
\hline 4 & $\begin{array}{l}\text { The Difficult concepts /graphs in this unit } \\
\text { have become vivid and clearer by the self- } \\
\text { directed learning }\end{array}$ & 0 & 3 & 28 & 50 & 4 & 79.3 \\
\hline 5 & $\begin{array}{l}\text { The exercise helped me get some novel } \\
\text { ideas for research project }\end{array}$ & 0 & 12 & 44 & 26 & 2 & 69.0 \\
\hline 6 & $\begin{array}{l}\text { I would advise the junior batches to go for } \\
\text { TBL }\end{array}$ & 1 & 3 & 9 & 47 & 25 & 84.2 \\
\hline 7 & $\begin{array}{l}\text { I realised that self-study, discussion and } \\
\text { teamwork help in better understanding of } \\
\text { the topic }\end{array}$ & 0 & 0 & 9 & 45 & 30 & 88.0 \\
\hline 8 & $\begin{array}{l}\text { The study material given was sufficient } \\
\text { and fool proof for the detailed study for } \\
\text { the topic }\end{array}$ & 2 & 5 & 28 & 38 & 11 & 78.2 \\
\hline 9 & $\begin{array}{l}\text { I saw the whole process as valuable and } \\
\text { not a waste of time and resources }\end{array}$ & 0 & 4 & 4 & 29 & 10 & 80.9 \\
\hline 10 & $\begin{array}{l}\text { I have you learnt and acknowledged the } \\
\text { importance of Peer Learning }\end{array}$ & 0 & 0 & 8 & 60 & 18 & 84.6 \\
\hline 11 & $\begin{array}{l}\text { The activity helped in overcoming shyness } \\
\text { and hesitation in the class }\end{array}$ & 2 & 4 & 14 & 24 & 6 & 75.6 \\
\hline 12 & $\begin{array}{l}\text { I have developed better rapport with my } \\
\text { teacher }\end{array}$ & 0 & 6 & 20 & 50 & 14 & 80.6 \\
\hline 13 & $\begin{array}{l}\text { I have attain the depth of knowledge of the } \\
\text { topic covered and can solve any difficulty } \\
\text { level questions from this topic }\end{array}$ & 0 & 5 & 27 & 44 & 15 & 81.6 \\
\hline 14 & $\begin{array}{l}\text { I received enough emotional support by } \\
\text { the faculty before and after (positive } \\
\text { criticism) my presentation in front of the } \\
\text { class }\end{array}$ & 0 & 1 & 24 & 42 & 17 & 85.0 \\
\hline 15 & $\begin{array}{l}\text { I want this } \mathrm{T} / \mathrm{L} \text { exercise to be conducted in } \\
\text { other departments also }\end{array}$ & 0 & 1 & 22 & 43 & 19 & 85.4 \\
\hline
\end{tabular}


usually do not interact with their teachers or peers, were motivated to participate in the activity with full zest. In addition, as teams work together and compete with other teams, sense of responsibility and loyalty to the team develops among the team members.

In the Indian context, the academic culture in most Medical Schools is to encourage the established conventional approach as pedagogy. But the paradigm is now shifting as fresh recruited teachers have joined in and have incorporated TBL and small group learning as part of the teaching learning exercise (19). Working effectively as a team in TBL method where every member shoulders equal responsibility has been well recognised by the Western medical educators as competencebased $(20,21)$.

The study shows that TBL requires much hard work from both, the teachers as well as the students, hence it is difficult to incorporate this method for all the topics. We suggest that it would be a good practice to conduct such sessions at the final stage of each professionals, focussing on the more difficult topics. The evaluation through feedback questionnaire helped us in knowing the students' perception with regards to TBL. It also aided us in identifying potential problems related to preclass assignments, team dynamics, studentfaculty relations, and overall learning. This would be helpful in improving the subsequent TBL sessions.

\section{Study Limitations}

There were time constraints and not all department faculty and residents could attend all the sessions. Not all doubts of the participants could be clarified in the assigned time duration. The whole TBL was tailor made according to our needs and resources; exhaustive study if desired can only be done when TBL is taken into account with all the steps planned meticulously and incorporation of flawless MCQs.

\section{Conclusion}

TBL is a learner-centred instructional strategy for both the instructor and the students, providing students with regular opportunities to learn how to collaborate with the peers. It is the need of the hour for learning modern medicine as it emphasises on accountability, decision making and collaboration with peers; all of which are essential for adult learning and developing competencies for healthcare professionals. Our study shows that TBL method may also be applicable in contexts beyond Western ones, that it is also suitable in cultures that mostly employ 'traditional' approach to teaching and learning.

We conclude that TBL can be used as a complement to didactic lectures for difficult topics in Indian medical schools and strategically be used for promoting the development of cognitive, psychomotor as well as affective domains. MCI vision 2015 document states that there should be Competence Based Education in Medicine and TBL is one such method.

\section{Acknowledgement}

This work was carried as part of Foundation for Advancement of International Medical Education and Research (FAIMER) project under Christian Medical College (CMC) Ludhiana. We render our gratitude to the facultyin-charge and all senior mentors of CMC Ludhiana.

\section{Conflict of Interest}

None.

\section{References}

1. Minhas PS, Ghosh A, Swanzy L (2012). The effects of passive and active learning on student preference and performance in an undergraduate basic science course. Anat Sci Educ 5:200-207. 
2. Allikmets S, Vink JP (2016). The benefits of peer-led teaching in medical education. Adv Med Educ Pract 7:329-330.

3. Wilke RR (2003). The effect of active learning on student characteristics in a human physiology course for non majors. Adv Physiol Educ 27:207-223.

4. Haidet P, Morgan RO, O'Malley K, Moran BJ, Richards BF (2004). A controlled trial of active versus passive learning strategies in a large group setting. Adv Health Sci Educ Theory Pract 9:15-17.

5. Rao YK, Shenoy GK (2013). Introducing team based learning in undergraduate pharmacology. Indian J Pharmacol 45(1):102-103.

6. Shigli K, Aswini YB, Fulari D, Sankeshwari B, Huddar D, Vikneshan M (2017). Case-based learning: a study to ascertain the effectiveness in enhancing the knowledge among interns of an Indian dental institute. J Indian Prosthodont Soc 17:29-34.

7. Rawekar A, Garg V, Jagzape A, Deshpande V, Tankhiwale S, Chalak S (2013). Team-based learning: a controlled trial of active learning in a large group setting. IOSR J Dental Med Sci 7:42-48.

8. Punja D, Kalludi SN, Pai KM, Rao RK, Dhar M (2014). Team-based learning as a teaching strategy for first-year medical students. Australas MedJ7(12):490-499.

9. Haidet P, O'Malley KJ, Richards B (2002). An initial experience with "team learning" in medical education. Acad Med J Assoc Am Med Coll 77:40-44.

10. Boyle J (2005). Lehninger Principles of Biochemistry, 4th edn. Nelson D, Cox M, eds. Biochem Mol Biol Educ 33:74-75.
11. Thomas PA, Bowen CW (2011). A controlled trial of team-based learning in an ambulatory medicine clerkship for medical students. Teach Learn Med 23:3136.

12. Deardorff AS, Moore JA, McCormick C, Koles PG, Borges NJ (2014). Incentive structure in team-based learning: graded versus ungraded Group Application exercises. JEduc Eval Health Prof 11:6.

13. Thompson BM, Schneider VF, Haidet $\mathrm{P}$, et al (2007). Team-based learning at ten medical schools: two years later. Med Educ 41:250-257.

14. Vasan NS, DeFouw DO (2008). Modified use of team-based learning for effective delivery of medical anatomy and embryology. Anat Sci Educ 1:3-9.

15. Wolff M, Wagner MJ, Poznanski S, Schiller J, Santen S (2015). Not another boring lecture: engaging learners with active learning techniques. $J$ Emerg Med 48:85-93.

16. Mcinerney MJ, Fink LD (2003). Teambased learning enhances long-term retention and critical thinking in an undergraduate microbial physiology course. Microbiol Educ 4:3-12.

17. Beatty SJ, Kelley KA, Metzger AH, Bellebaum KL, McAuley JW (2009). Team-based learning in therapeutics workshop sessions. Am J Pharm Educ 73:100.

18. Hazel SJ, Heberle N, McEwen MM, Adams K (2013). Team-based learning increases active engagement and enhances development of teamwork and communication skills in a first-year course for veterinary and animal science undergraduates. J Vet Med Educ 40:333341. 
19. Shellenberger S, Seale JP, Harris DL, Johnson JA, Dodrill CL, Velasquez MM (2009). Applying team-based learning in primary care residency programs to increase patient alcohol screenings and brief interventions. Acad Med 84:340346.

20. Ismail NA (2016). Effectiveness of TeamBased Learning in teaching medical genetics to medical undergraduates. Malays JMed Sci 23:73-77.
21. Farland MZ, Sicat BL, Franks AS, Pater KS, Medina MS, Persky AM (2013). Best practices for implementing team-based learning in pharmacy education. $A m J$ Pharm Educ 77:9. 